\title{
Development of radial access for primary percutaneous coronary intervention in ST-segment elevation myocardial infarction in Slavonski Brod: the long road to success
}

\section{Irzal Hadžibegović *, Božo Vujeva, Krešimir Gabaldo, Ognjen Čančarević, Đeiti Prvulović}

General Hospital "Dr. Josip Benčević", Slavonski Brod, Croatia

\section{RECEIVED:}

February 9, 2016

ACCEPTED:

February 20, 2016

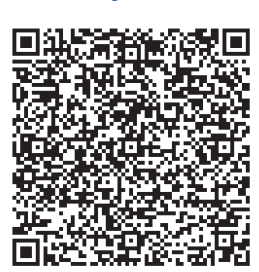

KEYWORDS: ST-segment elevation myocardial infarction, primary percutaneous coronary intervention, radial access.

CITATION: Cardiol Croat. 2016;11(3-4):100. | DOI: http://dx.doi.org/10.15836/ccar2016.100

*ADDRESS FOR CORRESPONDENCE: Irzal Hadžibegović, Opća bolnica "Dr. Josip Benčević", Andrije Štampara 42, HR-35000 Slavonski Brod, Croatia. / Phone: +385-91-533-3091 / E-mail: irzalh@gmail.com

ORCID: Irzal Hadžibegović, http://orcid.org/0000-0002-3768-9134 • Božo Vujeva, http://orcid.org/0000-0003-0490-3832 Krešimir Gabaldo, http://orcid.org/0000-0002-0116-5929 • Ognjen Čančarević, http://orcid.org/0000-0002-1285-8042 Đeiti Prvulović, http://orcid.org/0000-0002-8041-1197

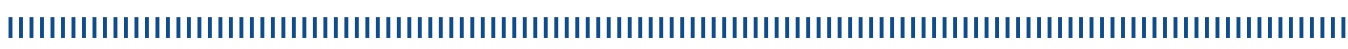

Background: Current ESC/EACTS Guidelines on myocardial revascularization emphasized benefit of radial access over femoral access in ST-segment elevation myocardial infarction (STEMI) if performed by an experienced radial operator. There are several definitions of an experienced radial operator. One of them is less than $10 \%$ of conversions from radial to femoral approach, and is often used in practice. The other is certainly volume, with 100 procedures as a primary operator needed to be securely on the upslope of the learning curve., ${ }^{1,2}$ We present our experience of long transition from femoral to radial access for primary percutaneous coronary intervention (PCI) in STEMI, mostly due to technical limitations and practical and organizational issues.

Patients and Results: Data from catheterization laboratory registries in Slavonski Brod from 2004 to 2016 were analyzed. Radial approach was first introduced systematically in mid 2012 after a 3-day radial access workshop in Slavonski Brod. Proportions of patients with radial access in 2012, 2013, 2014, and 2015 were $5 \%, 22 \%, 15 \%$, and $18 \%$, respectively. In $201270 \%$ of radial access was right radial, but in 2013 right radial access was used in only 25\% of radial cases. In 2014 and 2015 right radial was used again in most patients (86\% and 83\% of all radial, respectively). From 2012 to 2015, proportions of radial access in STEMI were small, varying between $3 \%$ and $6 \%$, and were mostly driven by impossible femoral access. In first two moths of 2016, after the installation of new coronary angiography suite with adequate room and table options for radial access, and additional education in a high volume radial center in University Hospital Centre Rijeka, Croatia, routine right radial access climbed suddenly to $76 \%$, with $4 \%$ of left radial access reserved mainly for left internal mammary artery bypass graft coronary angiography. Conversion to femoral access varied among operators from $6 \%$ to $14 \%$ during first two months in 2016, that led to routine introduction of radial access in STEMI by the end of January 2016 for 2 out of 5 operators. In first two months of 2016, 40\% of STEMI patients had right radial access, with no prolongation of door to balloon time noted.

Conclusion: Very long transition from femoral to radial access in STEMI, expected to reach a maximum of $90 \%$ of STEMI cases by June 2016 , was mainly driven by technical limitations of catheterization laboratory suite, and organizational issues with varying approaches and equipment used in the learning curve. $\square$ Cardiologia Croatica 2016;11(3-4):100.
LITERATURE IIIIIIIIIIIIIIIIIIIIIIIIIIIIIIIIIIIIIIIIIIIIIIIIIIIIIIIIIIIIIIIIIIIIIIIIIIIIIIIIIIIIIIIIIIIIIIIIIIII

1. Authors/Task Force members, Windecker S, Kolh P, Alfonso F, Collet JP, Cremer J, Falk V, et al. 2014 ESC/EACTS Guidelines on myocardial revascularization: The Task Force on Myocardial Revascularization of the European Society of Cardiology (ESC) and the European Association for Cardio-Thoracic Surgery (EACTS)Developed with the special contribution of the European Association of Percutaneous Cardiovascular Interventions (EAPCI). Eur Heart J. 2014;35(37):2541-619. DOI: http://dx.doi.org/10.1093/eurheartj/ehu278

2. Gellen B, Lesault PF, Canouï-Poitrine F, Champagne S, Mouillet G, Pongas D, et al. Feasibility limits of transradial pPCI in acute myocardial infarction in the real life (TRAP-AMI). Int J Cardiol. 2013;168(2):1056-61. DOI: http://dx.doi.org/10.1016/j.ijcard.2012.10.024 